\title{
Opening the Tomb of New Philosophical Accounts of Death
}

\author{
Thom Brooks ${ }^{1}$
}

Published online: 19 May 2018

(C) The Author(s) 2018

Many efforts are directed towards philosophical accounts of life from life's meaning to how it should be led. Often overlooked are no less important issues concerning the end of life. Questions like what is death?, is immortality desirable?, is death 'bad' for the person who dies?, can the dead be harmed or punished? and what, if any, obligations do we have towards the dead? - these are but a few key concerns deserving greater attention.

This special issue brings together three contributions that chart promising new perspectives on this timeless philosophical pastime. The first piece by Ben Curtis asks 'when do persons die?' ${ }^{1}$ Curtis focuses on the general thesis that death is constituted by the death of the human organism. Not all agree: some critics defend a 'two-deaths thesis' maintaining that the death of an organism is not the same as the death of a person. So which view is most compelling?

Curtis begins by examining Jeff McMahan's critique of the 'one-death' thesis that my personal identity is the same as my identity as an organism. ${ }^{2}$ The problem is that what a person is can change over time, starting as a zygote. The claim is that my personal identity is not fixed, but separable to my existence as an organism. Furthermore, identical twins - as organisms - exist as a single zygote that undergoes twinning developing into two different persons. This raises questions about whether my personal identity can be the same as my being an organism, at least in cases like this.

For Curtis, these claims fail as knock-out arguments against the 'one-death' thesis. A person's existence in some organism form may change, but it is suggested

\footnotetext{
1 See Ben Curtis, 'When Do Persons Die? Indeterminacy, Death, and Referential Eligibility' in this issue.

2 See Jeff McMahan, 'The Metaphysics of Brain Death', Bioethics 9 (2)(1995): 91-126.

Thom Brooks

thom.brooks@durham.ac.uk

1 Durham, UK
} 
by Curtis that this does not rule out that when my organic life ends so does my personal life - the two are inextricably bound however complex their relationship. More specifically, Curtis claims that a term like a 'person' is a phrase sortal that applies to some thing with particular properties, but these properties are also inessential. His example is that a king who abdicates the thrown may no longer be king, but the king can endure his abdication.

In short, the term 'person' is indeterminate biologically as well as psychologically. Curtis argues that therefore it is indeterminate whether the one-death or twodeaths thesis is true. However, if we accept that a person's 'being an organism' is a natural property and so refer to organisms when using the term, then persons are identical with their organisms: we die as our organisms die.

As Curtis attempts to revive the one-death thesis, Aaron Wolff tries to resurrect concurrentism: this is the view that death can be bad for a person when it happens. ${ }^{3}$ He begins with Epicurus, who observed that if death makes someone worse off, there is a question about when that happens if they no longer exist when dead. This 'timing puzzle' about when, if at all, death can be bad for the person who dies led Epicurus to claim death cannot be bad for that person.

Wolff disagrees. He argues that there are many different ways that something can be bad for us whether for our well-being or our financial accounts. He defends a 'relevant events view' (REV). We should consider the relevant events affected by an occurrence. Drinking non-fatal poison may harm our ability to enjoy future opportunities as well, but it also is a harm at the point of ingestion. Cases like these are used to build up the intuition that we are intrinsically worse off in some respect that we might have been otherwise had an occasion not taken place, like ingesting poison, spraining an ankle or dying. Wolff argues that his REV approach can make best sense not only of how death can be a bad for those who die at the time of their death, but speak broadly of other types of non-fatal deprivations as harms.

The trio of papers concludes with a look at post-death. Can we punish the dead? Saul Smilansky considers whether morality ends with our death. ${ }^{4}$ On the one hand, we appear to maintain widespread obligations towards the dead, such as honouring wills. On the other hand, there is little discussion about whether we had a more negative obligation, such as to 'harm some dead people'.

Smilansky begins by arguing we can be harmed without knowing it, like the case of a husband who is unknowingly betrayed by his wife when she visits her lover. Many individuals - not least brutal dictators - care to be remembered fondly on their deaths. One way to punish the dead could be to disappoint such expectations. Smilansky claims that if dictators knew about such possibilities, this might have some deterrent effect and serve as some kind of brake on their harming civilians while in power. ${ }^{5}$

Punishing the dead in this way could also be a means to benefiting the dead, such as the 'humiliated, tortured and murdered' ${ }^{6}$ Instead of seeking revenge against the

\footnotetext{
3 See Aaron Wolff, 'Reviving Concurrentism about Death' in this issue.

${ }^{4}$ See Saul Smilansky, 'Punishing the Dead' in this issue.

5 On deterrent punishments, see Thom Brooks, Punishment (London: Routledge, 2012).

${ }^{6}$ See Smilansky, 'Punishing the Dead' in this issue.
} 
living descendants of the deserving, harm would be directed to those who had been responsible while alive.

Smilansky acknowledges that there may be objections to such activities as morbid or retributivist. Yet he argues that there is nothing especially healthy about remaining repressed and doing nothing because those guilty of great wrongs have died. There are ways in which 'the dead continue to harm us': where we could not punish someone while alive, addressing their legacies can be one way of supporting victims and redressing an imbalance.

This special issue began its life as a conference held at Newcastle University jointly hosted by myself with Andrew I. Cohen of Georgia State University. Together, we selected speakers, ran parallel sessions and keynotes and chose the articles included in this Journal. Many thanks once more to our institutions, especially Georgia State's Jean Beer Blumenfeld Centre for Ethics and the Newcastle Ethics, Legal and Political Philosophy Group, for making the event possible. Most especially, my thanks to the authors for leading insightful discussions on this neglected area. I leave to others whether it is best to understand whether earlier drafts have died or become reborn as I open a philosophical tomb more akin to a treasure chest of new thinking and much needed perspectives about the philosophy - and philosophies - of death.

Open Access This article is distributed under the terms of the Creative Commons Attribution 4.0 International License (http://creativecommons.org/licenses/by/4.0/), which permits unrestricted use, distribution, and reproduction in any medium, provided you give appropriate credit to the original author(s) and the source, provide a link to the Creative Commons license, and indicate if changes were made. 